\title{
Precipitation-soil water chemistry relationship: case study of an intensively managed grassland ecosystem in southwest England
}

\author{
Adebayo Oluwole Eludoyin ${ }^{1}$
}

Received: 8 January 2016 / Accepted: 17 April 2020 / Published online: 30 April 2020

(c) The Author(s) 2020

\begin{abstract}
Environmental assessments typically require fine- or high-resolution datasets, example of which the Environmental Change Network (ECN) provides. This study has therefore taken advantage of the free access to the datasets to investigate temporal characteristics of precipitation and soil water chemistry, and relationship between the concentration of selected chemical variables in precipitation and soil water at $0-10 \mathrm{~cm}$ and below $10 \mathrm{~cm}$ depths based on data availability. The aim was to determine whether observations from the ECN data support results from the previous hypothesis on dominant run-off mechanism at the study area. Method of analysis involves inferential statistics and wavelet transform plot of selected physico-chemical variables for six (2010-2016) years. Results showed that most of the selected chemical variables exhibited low coefficient of determination in the relationship of their concentration in precipitation and soil water. Relatively linear relationships, however, occurred in the values of conductivity, $\mathrm{Cl}^{-}, \mathrm{Ca}^{2+}$, alkalinity and $\mathrm{Mg}^{2+}$ between the $0-10 \mathrm{~cm}$ and below $10 \mathrm{~cm}$ depths, indicating mixing of soil water at both soil zones. Inference from the results suggests a possible significant role of pre-event water or geological influence on soil water chemistry. The study affirms the hypothesis that saturation overland flow dominates areas underlain by Halstow soil series in the area.
\end{abstract}

Keywords Ion balance $\cdot$ Precipitation chemistry $\cdot$ Run-off processes $\cdot$ Soil water chemistry $\cdot$ Wavelet analysis

\section{Introduction}

Many researches on catchment hydrology have emphasized the importance of soil in the understanding of dynamics of stream water chemistry (Song et al. 2011; Hsu, et al. 2017). Activities within and outside as well as the characteristics of the soil are important determinants of the chemistry of water that travels past the soil into the stream (McGivney et al. 2019). Soil physical and chemical characteristics, as well as dominant land use/cover, have been reported to be capable of regulating the terrestrial freshwater supply, residence of water and chemistry of stream water (Eludoyin 2013; Jia et al. 2019; Zhi et al. 2019). Water transport through soils tends to be dominated by preferential flow through large pores (Allen et al. 2019), and water is often primarily stored in the finer matrix (Beven and Germann 1982).

Adebayo Oluwole Eludoyin

oaeludoyin@yahoo.com

1 Department of Geography, Obafemi Awolowo University, Ile-Ife, Nigeria
In addition to the immediate factors around the soil is precipitation. Existing studies have also shown that soil responds to precipitation chemistry. For example, McGivney et al. (2019) reported that soil acidification in selected Swedish conifer sites was associated with the level of acidification of rainwater received at the sites. Precipitation is described as the most effective scavenging factor for removing particulate and dissolved gaseous pollutants from the atmosphere, and as such, the chemistry of precipitation reflects the chemical composition of the atmosphere (Al-Khashman 2005). Studies of atmospheric inputs have increased in the last few decades, as public concerns about acid deposition and the subsequent acidification on waterbodies and vegetation have become pronounced increased (Cape and Fowler 1981; Beverland et al. 1998; Neal et al. 1997; Irwin et al. 2002; Jia et al. 2019; McGivney et al. 2019). Precipitation chemistry has also been monitored as preventive measures for meso- and micro-scale assessments (Cerny et al. 1994; McDowell et al. 2013; Miller and Zégre 2014; Evans et al. 2014). Studies have evaluated precipitation chemistry and its influence on the ecosystem through the chemical or ion mass balance approach, which visualizes the cause-effect 
concept of precipitation-ecosystem relationship as a system of inputs, internal fluxes and outputs (Giusti and Neal 1993; Cerny et al. 1994); the inputs are fluxes of substances that are introduced into the catchment system through precipitation, while the outputs are the effects which are typically measured or determined in run-off chemistry, and these often vary with discharge (Cresser et al. 1987; Kvaalen et al. 2002; Xie et al. 2019).

Precipitation is known to assert impact on the mobilization of chemical ions in the ecosystem and can cause important changes in the chemistry and quality (relative to agricultural use, pollution, domestic use in some poor communities) of soil water and adjacent streams. Sources of atmospheric inputs have been widely studied and are distributed into those which are transferred through natural and anthropogenic sources, most of which are removed by precipitation as wet deposition by in-cloud (including snowout and rainout) and below-cloud (washout or erosion) processes. The anthropogenic sources have been linked to the effects of urbanization, industrialization or commercialization, and physical/mechanical and chemical weathering processes as well as marine deposition are among the natural sources (Cerny et al. 1994). In the UK, studies (Damgaard et al. 2014; Evans et al. 2014) linked change in the precipitation chemistry to significant alteration in the population wet heathlands species (Erica tetralix by about $10 \%$ in a 5-year period) in northern England, while many others have linked change in run-off chemistry during storm event to the mobilization effects of precipitation (Cresser and Edwards 1987; Eludoyin 2013; Eludoyin et al. 2017).

\section{Research problem}

The three end-member mixing analysis (EMMA) model used by catchment water scientists to distinguish different sources of stream water identifies precipitation, along with soil water and groundwater, as a distinct source (Jenkins et al. 1994; Evans and Davies 1998; Eludoyin 2013). Successive evaluation of EMMA and hysteresis approach towards stream chemistry examination also reveals the importance of soil moisture, characteristics and dominant activities on the soil (Benettin et al. 2017; Eludoyin et al. 2017; Wymore et al. 2019). However, studies are many and many are evolving on precipitation chemistry and stream chemistry; information on the relationship between the chemistry of precipitation and soil water chemistry is still scanty. A Google Scholar search of studies published between 2020 and 2016, using the keyword 'relationship between precipitation and soil water chemistry', reveals that except from McHale et al. (2017), which focused on response on soil and stream chemistry to change in acid deposition, and Sigler et al. (2018), which attempted an investigation of the connection among soil, ground and surface water, there are too few studies which attempted an elucidation of soil water chemistry in relation to precipitation chemistry. Also, studies relating to catchment-scale effect are expected to be localized despite that rainfall chemistry and acidification are transboundary, probably because catchments tend to exhibit spatial and temporal behavioural changes (Soulsby et al. 2003). A general consensus among studies is that a nonlinear (rather than linear) relationship occurs in the relationship of precipitation (input) and stream (output) chemistry, and this is largely due to the activities within and outside, as well as the characteristics of the soil.

This study aims at improving the scientific understanding of water flowpaths by examining the degree at which soil chemistry in a clay-rich soil can be influenced by the chemistry of the precipitation it receives. The objectives of this study are to examine the temporal characteristics of precipitation and soil water chemistry and assess the relationship between the concentration of selected chemical variables in precipitation and soil water at both shallow $(0-10 \mathrm{~cm})$ and deep $(>10 \mathrm{~cm})$ soil levels at one of the Environmental Change Network (ECN) stations in the UK. The ECN is an integrated information resource database for long-term monitoring and research purpose (Lane 1997). The study area, North Wyke Research Centre, is home to the BBRSCsponsored Farm Platform of Rothamsted Research in the UK, where the author conducted his doctoral research on the hysteresis in the relationship between discharge and solute concentrations at farm scale (Eludoyin 2013). The outcome of the research reveals that improved understanding of the soil moisture and its chemistry is of significant importance for detecting hydrological pathway, hence this study. The ECN describes the study area as 'a paddock of old biodiverse permanent grassland, which receives no nitrogen fertilizer input but has since 1984 been under controlled grazing' (Adamson 1996), and this is taken to reflect the part of the area from which data used for this study represent, in addition to the experimental use of the entire field in the recent time.

\section{Materials and methods}

\section{Data}

Rainfall (volume and chemistry) and soil water chemistry were sourced from the archives of the terrestrial sites of the Environmental Change Network (ECN) (http://www.ecn. ac.uk/) on one of the fields (Burrows) of the Rothamsted Research North Wyke Farm Platform (NWFP) in southwest England, UK $\left(50.77^{\circ} \mathrm{N}, 3.90^{\circ} \mathrm{W}\right.$, Fig. 1). The site is managed by a Protocol of the United Kingdom Joint Code for research 


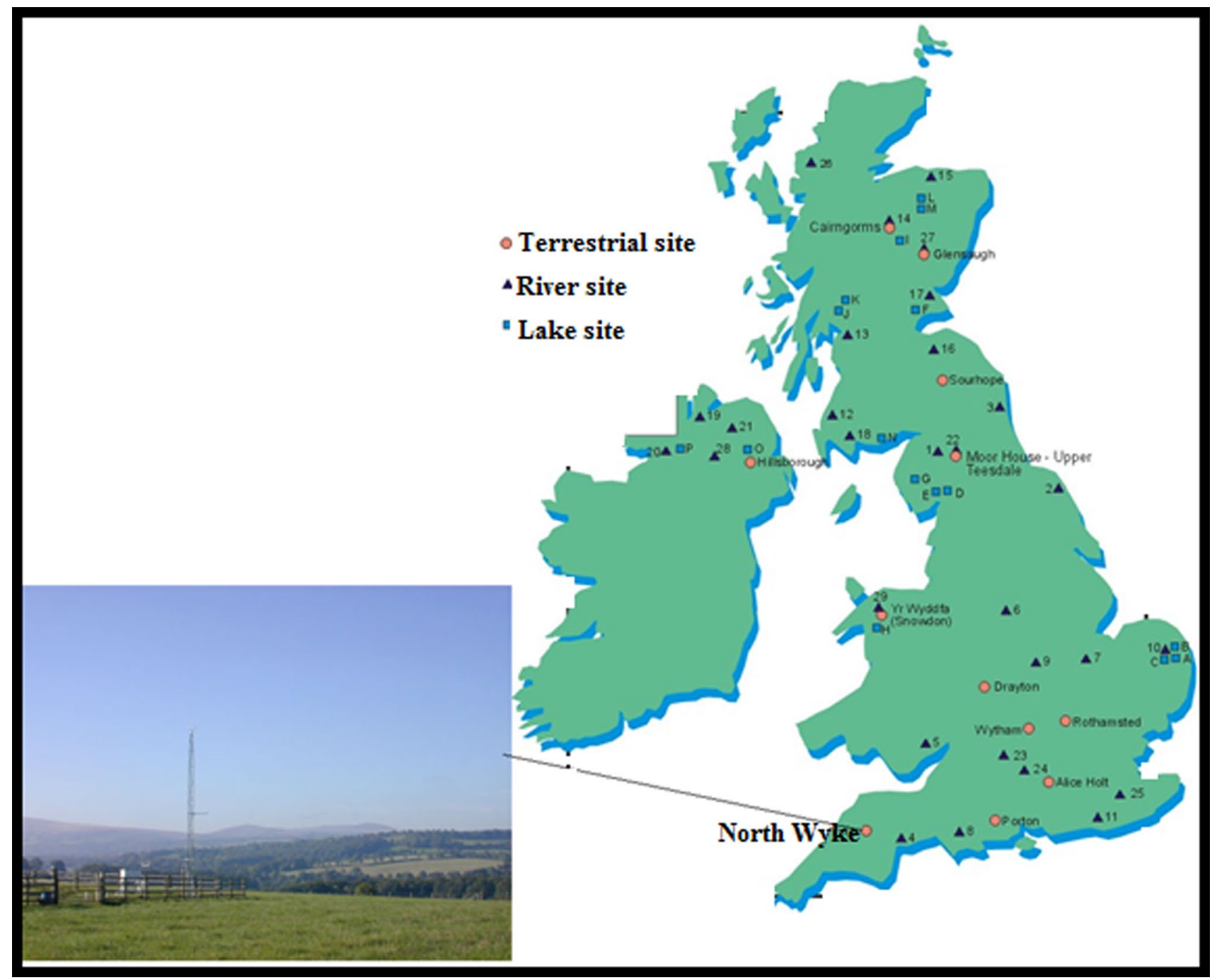

Fig. 1 Environment change network's terrestrial site at the North Wyke Farm platform in southwest England

for data quality assessment and maintenance of weather instruments (Sykes and Lane 1996; Morecroft et al. 2009).

The geology of the study area belongs to the Carboniferous Crackington Formation, a part of the 'Culm Measures' geology, which comprises sandstone and shale sequence of the extensive outcrop of Carboniferous strata in the Millstone Grit (Laming and Roche 2006; Harrod and Hogan 1981; Warrington et al. 2012). Soils overlying the Crackington Formation are usually clay rich with dark grey, black or weathered pale shales and thin subsidiary sandstone bands (Leslie et al. 2008). The field on which the ECN instruments are installed is dominantly occupied by the Hallsworth soil series of the Halstow Association (Avery 1980; Harrod and Hogan 1981; Farewell 2008). Halstow Association is generally classified to be of low potential groundwater movement (Harrod and Hogan 1981). Hallsworth soil series is also known as Stagni-Vertic Cambisols or Typic Haplaquept, and described as 'a clay pelostagnogley soil in head from clay shale' comprising of dominantly clayey and mottled soils of grey colour. The soil series is also described as being slowly permeable, seasonally waterlogged soils over slowly permeable substrates with negligible storage capacity. The soils are high leaching potential, which readily transmit liquid discharges because they are either shallow, or susceptible to rapid bypass flow directly to rock, gravel or groundwater (Harrod and Hogan 1981).

Plant communities at the study area are classified as 'MG7' (Rodwell 1992), comprising Lolium perenne leys and related grasslands. The MG7 plant community includes highly productive short-term agricultural grassland for grazing or mowing in rotation with arable farming, permanent amenity and recreational swards developed for heavy use (Rodwell 1992). Daily mean temperature range is between 5.97 and $12.16{ }^{\circ} \mathrm{C}$, while daily mean wind speed, rainfall, 
sunshine and relative humidity are $4.69 \mathrm{~m} \mathrm{~s}^{-1}, 4.30 \mathrm{~mm}$, $4.43 \mathrm{~h}$ and $77.33 \%$, respectively (Eludoyin 2013; Eludoyin et al. 2017). Average temperature and rainfall at the study area exhibited seasonal differences; temperature varied as $4.9 \pm 0.6{ }^{\circ} \mathrm{C}$ (winter), $8.2 \pm 2.3{ }^{\circ} \mathrm{C}$ (spring), $14.8 \pm 1.1{ }^{\circ} \mathrm{C}$ (summer) and $10.5 \pm 3.0^{\circ} \mathrm{C}$ (autumn), while rainfall varied seasonally as $119.3 \pm 21.1,101.0 \pm 18.3,72.0 \pm 10.6$ and $59.7 \pm 7.64 \mathrm{~mm}$ in winter, autumn, spring and summer, respectively.

\section{ECN instrumentation at study site}

Rainfall is measured with a tipping bucket rain gauge, while water samples for chemical analysis (bulk precipitation) were collected in a continuously open funnel bulk collector. The bulk collector is made up of a conical polythene funnel that rests on a polythene collecting bottle, with a funnel (152 $\mathrm{mm}$ diameter), placed at about $1.75 \mathrm{~m}$ above the ground level (Fig. 2) (Hall 1986). Information of daily weather was sourced from an automatic weather station in the study area. The collecting bottle is protected, from coarse debris and leaves falling into it, with a removable filter of 1-mm-mesh Teflon which is surrounded by a jacket of polished steel from which it is also separated by a $25-\mathrm{mm}$ gap. The collector is bird deterrent, and problems with birds have not been recorded since the station has become operational. Local sources of contamination are also avoided by placing the collector upwind of any of such sources, apart from being situated away from vehicle tracks, animal house and obstructions such as a building or tree. It is also firmly secured to the ground. Water sample is collected at 0900 UK Local Time on Wednesday of every week, by removing the bottle containing the precipitation sample (Adamson 1996). The bottle and the sample are labelled and subsequently taken to the laboratory, where the volume of precipitation is first determined to the nearest $1 \mathrm{ml}$. The used funnel is subsequently cleaned with deionized water and shaken to remove any droplets or replaced with another funnel that has been cleaned in the laboratory. The bottle that contained the precipitation is also replaced by a clean bottle fitted with a clean filter.

The ECN collects soil water samples that were collected at this site at $0-10 \mathrm{~cm}$ and $10-20 \mathrm{~cm}$ soil depths using the Prenart 'super quartz' soil water suction samplers (Fig. 2). The Prenart 'super quartz' soil water samplers are cylindrical, $21 \mathrm{~mm}$ in diameter and $95 \mathrm{~mm}$ in length, conical at one end and with a tube attachment at the other. The tubing links the sampler to a 1-L glass collecting bottle with a Prenart screw cap. The collecting bottles are placed in an insulated box to protect the samples from extremes of temperature and are evacuated using a portable pump. Samplers are located within a 6-m-by-6-m plot (which is itself located within a 10-m-by-10-m plot) at Burrows. Samplers are usually emptied into plastic bottles where water volumes are recorded before samples for chemical analysis are taken. The UK Environmental Change Network's laboratory at North Wyke determines conductivity and $\mathrm{pH}$ of the unfiltered water samples within seven hours of collection with $\mathrm{pH} /$ conductivity (a)

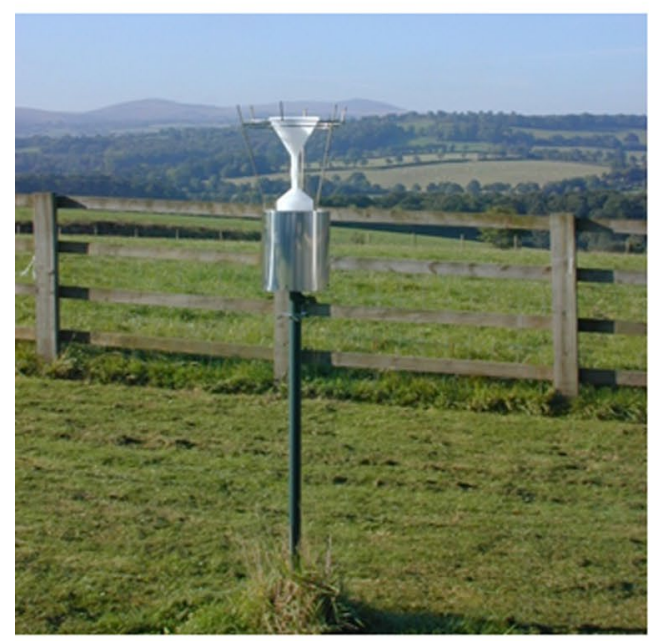

(b)

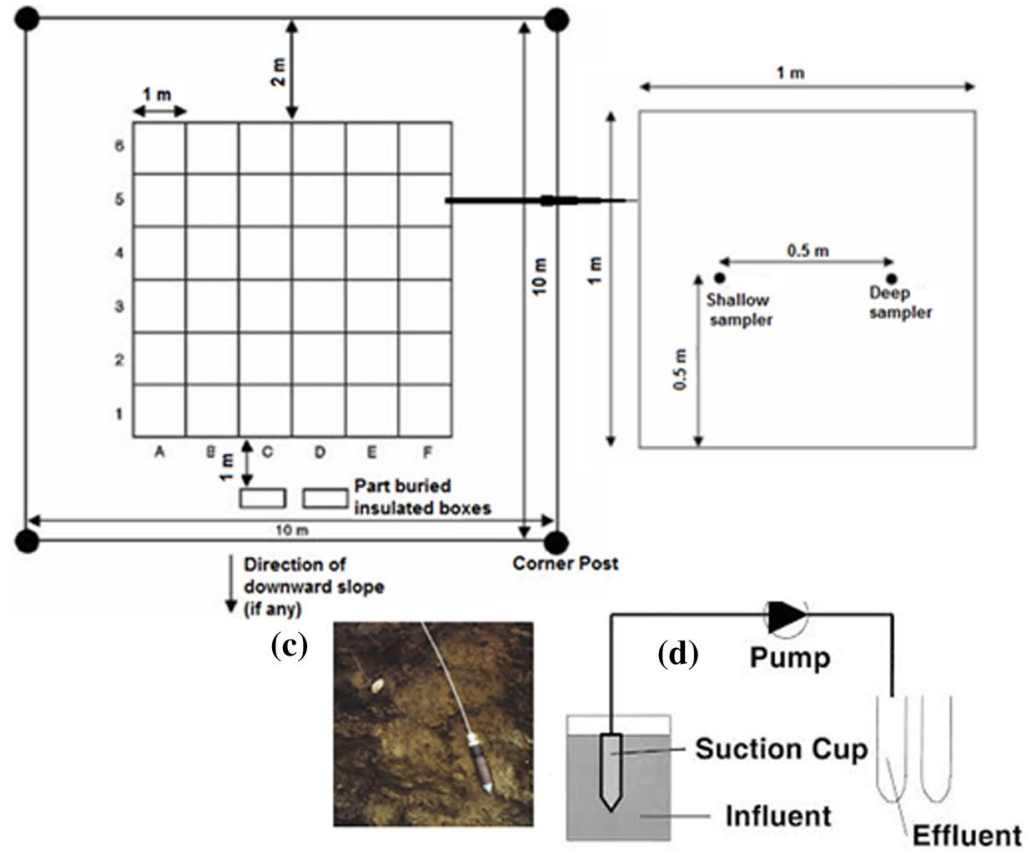

Fig. 2 Field instrumentation a is bulk precipitation collector. b-d show the site, physical appearance and mechanism of the soil water collector, respectively 
meter (Jenway Model 3320), while dissolved ions are determined in filtered samples as described by HMSO (1978, 1988) and Heyes et al. (1985) (Adamson and Sykes 1996). When not immediately analysed, samples were stored in a freezer at $1-4{ }^{\circ} \mathrm{C}$.

\section{Data analysis}

Data analysed in this study were the 2010-2016 biweekly bulk precipitation and soil water records of selected physical and chemical variables $(\mathrm{pH}$, conductivity and alkalinity, $\mathrm{Ca}^{2+}, \mathrm{Na}^{+}, \mathrm{Mg}^{2+}, \mathrm{K}^{+}, \mathrm{NH}_{4}, \mathrm{Cl}^{-}, \mathrm{NO}_{3}{ }^{-}, \mathrm{SO}_{4}{ }^{2-}$ and $\mathrm{PO}_{4}{ }^{3-}$ ) for the North Wyke ECN station. The soil chemistry data comprise those of $0-10 \mathrm{~cm}$ (shallow) and below $10 \mathrm{~cm}$ (deep) water solution. Data were first evaluated for general characteristics using summary statistics and were later inspected for time-series analysis using the wavelet transform method in Past 3 software. Torrence and Compo (1998) described wavelet analysis as useful for detecting periodicities at different wavelengths, self-similarity and other features in data series using a graphical plot in which the vertical axis is a logarithmic size scale (base 2), with the signal observed at a scale of only two consecutive data points at the top and at a scale of one fourth of the whole sequence at the bottom (Hammer 2016). The method involves extracting the wavelet power spectrum of the given time series using a continuous wavelet transform (CWT) in order to study the evolution of variance across different timescales. Detail information about wavelet analysis is documented by Lark and Webster (2001), Milne et al. (2009), among others. Furthermore, individual variables were compared among precipitation, shallow soil water and deep soil water using graphical methods, while significant difference per different variables was established using analysis of variance and post hoc multiple comparison (at $p \leq 0.05$ ). Trend was assessed with simple linear regression model used to establish whether there is a linear relationship as water (precipitation) infiltrates into the shallow soil and deep soil depths. Principal component analysis (PCA) was used to reduce the factors of the parameters and to deduce those which significantly $(p \leq 0.05)$ contributed to variations at each of precipitation, shallow soil and deep soil profile. The PCA is concerned with explaining the variance-covariance structure through a few linear combinations of the original variables, that is, the eigenvectors of the variance-covariance matrix.

\section{Results}

\section{Variations in values of selected chemical variables in precipitation and soil water}

The summary statistics of the selected variables is presented in Table 1. Precipitation was generally slightly acidic and contains lower concentration of most of the variables, except $\mathrm{K}^{+}, \mathrm{Fe}, \mathrm{Cl}^{-}$and $\mathrm{NO}_{3}^{-}$, which occurred in greater concentrations in the precipitation than in soil water (Fig. 3). The differences obtained in the mean values of the $\mathrm{Ca}^{2+}, \mathrm{Cl}^{-}$, conductivity, $\mathrm{K}^{+}, \mathrm{Mg}^{2+}, \mathrm{Na}^{+}, \mathrm{PO}_{4}{ }^{3-}$ and $\mathrm{SO}_{4}{ }^{3-}$ were significantly $(p \leq 0.05)$ different between precipitation and soil

Table 1 Mean, coefficient of variation and range of concentrations of selected physico-chemical variables

\begin{tabular}{|c|c|c|c|c|c|c|c|c|c|}
\hline \multirow[t]{3}{*}{ Chemical variable } & \multirow{2}{*}{\multicolumn{3}{|c|}{ Bulk precipitation }} & \multicolumn{6}{|c|}{ Soil water solution (2010-2016) } \\
\hline & & & & \multicolumn{3}{|c|}{$0-10 \mathrm{~cm}$} & \multicolumn{3}{|c|}{ Below $10 \mathrm{~cm}$} \\
\hline & Mean & $\mathrm{CV}(\%)$ & Min-max & Mean & $\mathrm{CV}(\%)$ & Min-max & Mean & $\mathrm{CV}(\%)$ & Min-max \\
\hline $\mathrm{pH}$ & $5.15^{\mathrm{b}}$ & 6.01 & $4.18-5.79$ & $6.31^{\mathrm{a}}$ & 3.25 & $5.86-6.7$ & $6.30^{\mathrm{a}}$ & 2.51 & $5.97-6.88$ \\
\hline Alkalinity $\left(\mathrm{mg} \mathrm{l}^{-1}\right)$ & $3.86^{\mathrm{a}}$ & 154.24 & $0.00-33.05$ & $4.65^{\mathrm{a}}$ & 92.61 & $0.00-19.99$ & $7.02^{\mathrm{a}}$ & 33.05 & $0.90-37.02$ \\
\hline Conductivity $\left(\mu \mathrm{S} \mathrm{cm}^{-1}\right)$ & $28.64^{\mathrm{b}}$ & 48.86 & $10.47-63.93$ & $46.04^{\mathrm{a}}$ & 22.82 & $24.39-64.35$ & $50.32^{\mathrm{a}}$ & 14.38 & $32.22-64.60$ \\
\hline $\mathrm{Na}^{+}\left(\mathrm{mg} \mathrm{l}^{-1}\right)$ & $3.10^{\mathrm{b}}$ & 74.10 & $0.40-9.82$ & $5.66^{\mathrm{a}}$ & 15.92 & $3.69-7.72$ & $5.41^{\mathrm{a}}$ & 9.45 & $4.12-6.57$ \\
\hline $\mathrm{K}^{+}\left(\mathrm{mg}^{-1}\right)$ & $0.19^{\mathrm{a}}$ & 78.89 & $0.04-0.63$ & $0.07^{\mathrm{b}}$ & 231.44 & $0.01-1.01$ & $0.09^{\mathrm{b}}$ & 12.52 & $0.01-0.50$ \\
\hline $\mathrm{Mg}^{2+}\left(\mathrm{mg} \mathrm{l}^{-1}\right)$ & $0.38^{\mathrm{b}}$ & 72.07 & $0.05-1.31$ & $0.95^{\mathrm{a}}$ & 39.51 & $0.30-1.92$ & $0.97^{\mathrm{a}}$ & 17.01 & $0.41-1.60$ \\
\hline $\mathrm{Ca}^{2+}\left(\mathrm{mg} \mathrm{l}^{-1}\right)$ & $0.31^{\mathrm{c}}$ & 56.32 & $0.12-0.72$ & $1.76^{\mathrm{b}}$ & 65.81 & $0.45-6.84$ & $2.64^{\mathrm{a}}$ & 13.99 & $0.93-5.19$ \\
\hline $\mathrm{NH}_{4}^{+}\left(\mathrm{mg} \mathrm{l}^{-1}\right)$ & $0.02^{\mathrm{a}}$ & 57.44 & $0.00-0.05$ & $0.02^{\mathrm{a}}$ & 66.49 & $0.00-0.06$ & $0.02^{\mathrm{a}}$ & 20.06 & $0.00-0.05$ \\
\hline $\mathrm{NO}_{3}^{-}\left(\mathrm{mg} \mathrm{l}^{-1}\right)$ & $2.54^{\mathrm{a}}$ & 324.47 & $0.08-36.63$ & $0.10^{\mathrm{a}}$ & 123.56 & $0.02-0.71$ & $0.12^{\mathrm{a}}$ & 17.43 & $0.01-0.59$ \\
\hline $\mathrm{Cl}^{-}\left(\mathrm{mg} \mathrm{l}^{-1}\right)$ & $11.89^{\mathrm{a}}$ & 183.63 & $1.18-87.2$ & $8.43^{\mathrm{a}}$ & 34.17 & $3.58-13.10$ & $8.26^{\mathrm{a}}$ & 17.81 & $3.10-11.92$ \\
\hline $\mathrm{PO}_{4}^{3-}\left(\mathrm{mg} \mathrm{l}^{-1}\right)$ & $0.01^{\mathrm{a}}$ & 195.96 & $0.00-0.12$ & $0.01^{\mathrm{a}}$ & 124.55 & $0.00-0.05$ & $0.01^{\mathrm{a}}$ & 24.32 & $0.00-0.06$ \\
\hline $\mathrm{SO}_{4}{ }^{2-}\left(\mathrm{mg} \mathrm{l}^{-1}\right)$ & $0.30^{\mathrm{b}}$ & 85.32 & $0.00-1.01$ & $1.68^{\mathrm{a}}$ & 32.44 & $1.01-3.75$ & $1.79^{\mathrm{a}}$ & 12.56 & $0.88-3.25$ \\
\hline $\mathrm{Fe}\left(\mathrm{mg} \mathrm{l}^{-1}\right)$ & $0.01^{\mathrm{a}}$ & 191.52 & $0.00-0.05$ & $0.01^{\mathrm{a}}$ & 225.73 & $0.00-0.08$ & $0.01^{\mathrm{a}}$ & 14.92 & $0.00-0.05$ \\
\hline $\mathrm{Al}^{3+}\left(\mathrm{mg} \mathrm{l}^{-1}\right)$ & $0.01^{\mathrm{a}}$ & 187.74 & $0.00-0.06$ & $0.01^{\mathrm{a}}$ & 76.31 & $0.00-0.03$ & $0.01^{\mathrm{a}}$ & 28.75 & $0.00-0.04$ \\
\hline
\end{tabular}

Means with same alphabet (lowercase) are not significantly $(p \leq 0.05)$ different from each other but are significantly different from means with different alphabets 

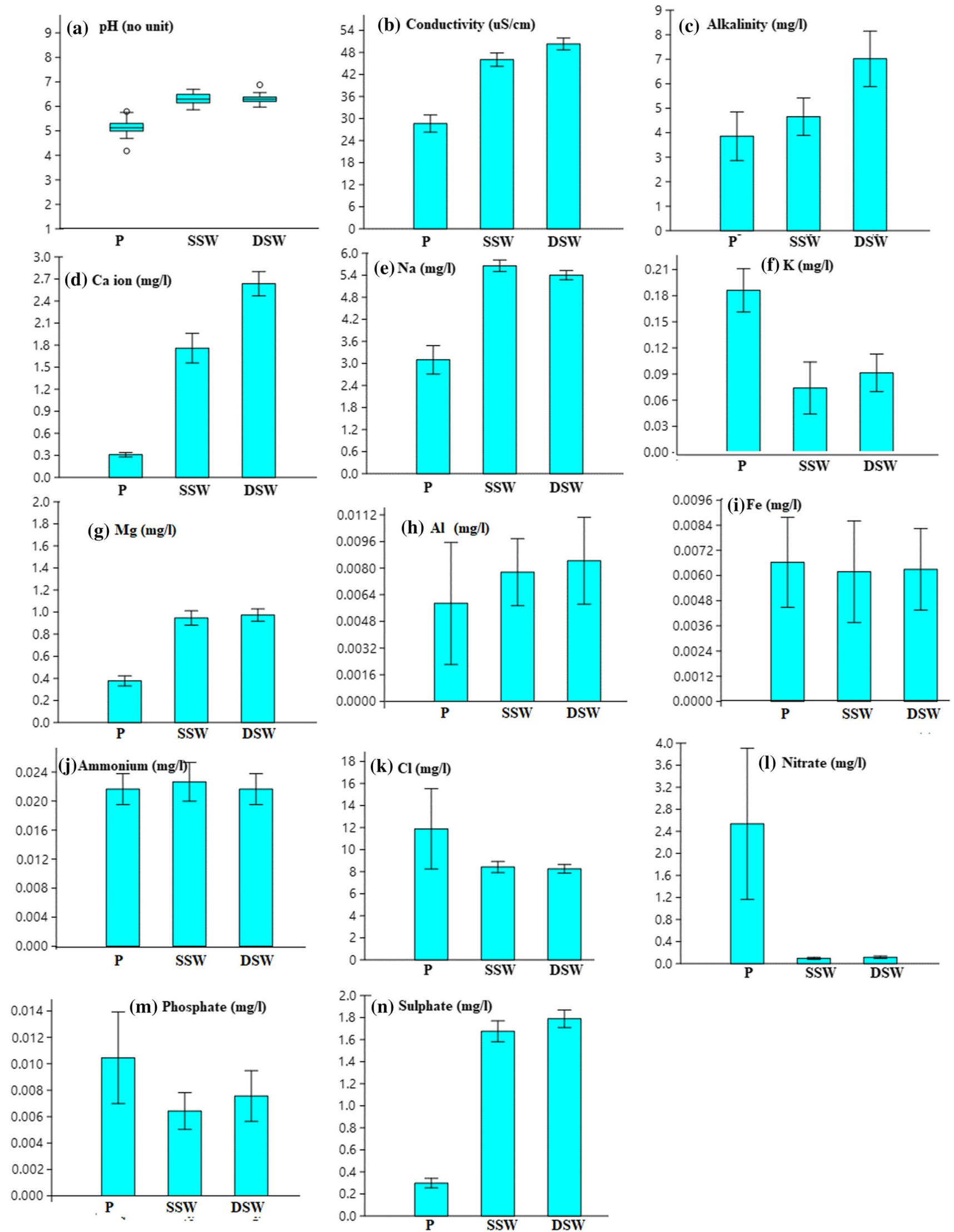

Fig. 3 Comparison of selected variables between precipitation and soil water samples 
water (at both $0-10 \mathrm{~cm}$ and $>10 \mathrm{~cm}$ depth). On the other hand, only $\mathrm{Ca}^{2+}$ exhibited significant differences between $0-10 \mathrm{~cm}$ and $>10 \mathrm{~cm}$ soil depths. The results of the assessment of variation suggest a significant difference between the chemistry of the precipitation and that of the soil water. It also indicates that except from calcium ions, the chemistry of the shallow and deep soil was not significantly different. Furthermore, the result of the PCA that was carried out to reduce the variables into important (when eigenvalues are at least 0.5 at either Factor 1 or 2) and non-important (with less than 0.5 eigenvalues at either Factor 1 or 2) revealed that conductivity, $\mathrm{Na}^{+}, \mathrm{Mg}^{2+}, \mathrm{Fe}$ and $\mathrm{Cl}^{-}$are the only common variables that explain the highest percentage in variance in either the precipitation or soil water samples (Fig. 4). Also, Fig. 4 shows that $\mathrm{Ca}^{2+}$ was only important in the soil water at both $0-10 \mathrm{~cm}$ and $>10 \mathrm{~cm}$ depth, but not in the precipitation.

\section{Comparison using ion balance equation}

Analysis of the ion balance for the average concentrations of the major ions and calculated TDS indicated that whereas $\mathrm{Na}^{+}$was the dominant cation in the precipitation, $\mathrm{Ca}^{2+}$ with the overall most abundant value dominated the below $10 \mathrm{~cm}$ soil water (Table 2). Chloride was the dominant anion in both precipitation and soil water, and it appears to increase as precipitation infiltrates deeper into the soil. The distribution of the variables in the soil water appears similar in the soil water at the two different depths that were investigated but were different from that observed with the precipitation. Whereas variables showed as $\mathrm{Cl}^{-}>\mathrm{Na}^{+}>$alkalinity $>\mathrm{NO}_{3}{ }^{-}>\mathrm{Ca}^{2+}>\mathrm{Mg}^{2+}>\mathrm{SO}_{4}{ }^{2-}$ in the precipitation, water chemistry at both soil $(0-10 \mathrm{~cm}$ and below $10 \mathrm{~cm})$ depths exhibited the order of $\mathrm{Ca}^{2+}>\mathrm{Na}^{+}>\mathrm{Cl}^{-}>$alkalinity $>\mathrm{Mg}^{2+}>\mathrm{SO}_{4}{ }^{2-}$. In general, chloride tends to decrease down the soil depth, while $\mathrm{Ca}^{2+}, \mathrm{Mg}^{2+}, \mathrm{SO}_{4}{ }^{2-}$ and alkalinity increased away from precipitation down the soil depth. Other ions, $\mathrm{Al}^{3-}, \mathrm{NH}_{4}, \mathrm{~K}^{+}, \mathrm{Fe}$ and $\mathrm{PO}_{4}{ }^{3-}$ exist in negligible concentration in their absolute value; $\mathrm{NO}_{3}{ }^{-}$also in the soil water was negligible.

Furthermore, percentage difference between the sums of cations and anions at all the stations was low (0.4-1.7\%) and was more with precipitation and least at below $10 \mathrm{~cm}$ soil water. On the other hand, calculated dissolved solids were more at the below $10 \mathrm{~cm}$ soil water than either $0-10 \mathrm{~cm}$ soil water or precipitation; it was least in the precipitation.

\section{Linear relationship between precipitation and soil water chemistry}

Table 3 shows equations of linear relationship between the each of the investigated chemical variables in precipitation and soil water at both $0-10 \mathrm{~cm}$ and below $10 \mathrm{~cm}$ depths. The values of the coefficient of determination $\left(R^{2}\right)$ for generated equations were generally low for the relationship between precipitation and sol water at $0-10 \mathrm{~cm}$, indicating that cause-effect relationship cannot be predicted with a singular linear relationship. On the other hand, relationship between the values of conductivity, $\mathrm{Cl}^{-}$, alkalinity and $\mathrm{Mg}^{2+}$ in the soil water at $0-10 \mathrm{~cm}$ and below $10 \mathrm{~cm}$ returned at least $40 \%$ coefficient of determination $\left(R^{2}=0.72,0.59\right.$, 0.44 and 0.41 , respectively). The four (conductivity, $\mathrm{Cl}^{-}$, alkalinity and $\mathrm{Mg}^{2+}$ ) exhibited an increasing trend down the soil profile (Table 3 ). Other ions with relatively higher $R^{2}$ ( 0.30 and above) are $\mathrm{NH}_{4}, \mathrm{Na}^{+}$and $\mathrm{pH}$ in the relationship between $0-10 \mathrm{~cm}$ and below $10 \mathrm{~cm}$ soil water, and $\mathrm{NH}_{4}$ and $\mathrm{pH}$ between precipitation and soil water at $0-10 \mathrm{~cm}$.

\section{Wavelet analysis}

Figure 5 shows the plots for investigated variables. The wavelet plots were produced with Morlet model which hypothesizes a sinusoidal pattern. Both precipitation and soil water data exhibited signal similarity in their patterns as none shows any clear band of consistent change at the upper limit; they all showed dints of low signals, which
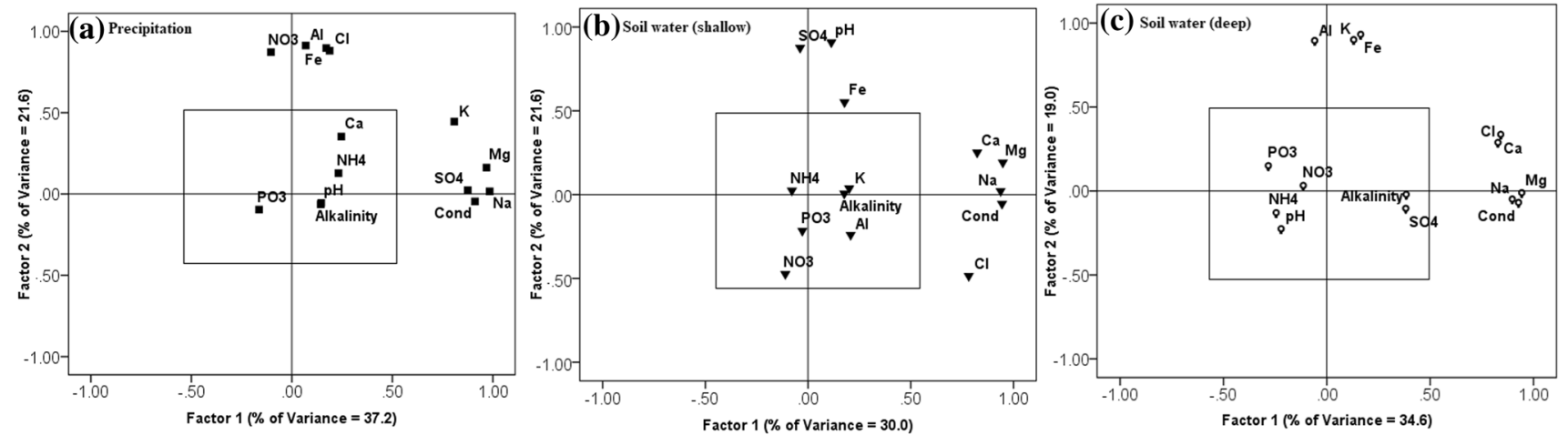

Fig. 4 PCA results showing the distribution of investigated parameters in the precipitation (P) and soil water (SSW and DSW; 0-10cm and below $10 \mathrm{~cm}$, respectively) 
Table 2 Ion balance estimates of precipitation and soil water chemistry
Table 3 Linear regression $(y=a \pm b x)$ in between the precipitation and soil water chemistry

\begin{tabular}{|c|c|c|c|c|c|c|}
\hline \multirow[t]{3}{*}{ Ion } & \multirow{2}{*}{\multicolumn{2}{|c|}{ Precipitation }} & \multicolumn{4}{|c|}{ Soil water } \\
\hline & & & \multicolumn{2}{|c|}{$0-10 \mathrm{~cm}$} & \multicolumn{2}{|c|}{ Below $10 \mathrm{~cm}$} \\
\hline & $m g 1^{-1}$ & meq $1^{-1}$ & $m g 1^{-1}$ & meq $1^{-1}$ & $m g 1^{-1}$ & meq $1^{-1}$ \\
\hline $\mathrm{Ca}^{2+}$ & 0.310 & 0.052 & 1.760 & 0.293 & 2.636 & 0.439 \\
\hline $\mathrm{Mg}^{2+}$ & 0.378 & 0.031 & 0.947 & 0.078 & 0.973 & 0.080 \\
\hline $\mathrm{K}^{+}$ & 0.186 & 0.005 & 0.074 & 0.002 & 0.091 & 0.002 \\
\hline $\mathrm{Al}^{3+}$ & 0.006 & 0.001 & 0.008 & 0.001 & 0.008 & 0.001 \\
\hline $\mathrm{Fe}^{2+}$ & 0.007 & 0.000 & 0.006 & 0.000 & 0.006 & 0.000 \\
\hline $\mathrm{Na}^{+}$ & 3.100 & 0.135 & 5.658 & 0.246 & 5.406 & 0.235 \\
\hline $\mathrm{NH}_{4}^{+}$ & 0.022 & 0.001 & 0.023 & 0.001 & 0.022 & 0.001 \\
\hline $\mathrm{SO}_{4}^{2-}$ & 0.299 & 0.007 & 1.676 & 0.037 & 1.790 & 0.040 \\
\hline $\mathrm{PO}_{4}^{3-}$ & 0.010 & 0.000 & 0.006 & 0.000 & 0.008 & 0.000 \\
\hline $\mathrm{Cl}^{-}$ & 11.892 & 0.335 & 8.425 & 0.238 & 8.263 & 0.233 \\
\hline $\mathrm{NO}_{3}^{-}$ & 2.538 & 0.041 & 0.096 & 0.002 & 0.116 & 0.002 \\
\hline $\mathrm{CaCO}_{3}^{2-}$ & 3.859 & 0.077 & 4.654 & 0.093 & 7.019 & 0.140 \\
\hline Calculated TDS & 22.605 & & 23.333 & & 26.339 & \\
\hline Sum of cations & & 0.224 & & 0.621 & & 0.759 \\
\hline Sum of anions & & 0.460 & & 0.370 & & 0.415 \\
\hline Cation-anion ratio & & 0.487 & & 1.681 & & 1.828 \\
\hline Cation + Anion & & 0.685 & & 0.991 & & 1.174 \\
\hline Cation-anion & & 0.012 & & 0.008 & & 0.005 \\
\hline$\%$ difference & & 1.752 & & 0.807 & & 0.426 \\
\hline
\end{tabular}

\begin{tabular}{|c|c|c|c|c|c|c|}
\hline \multirow[t]{3}{*}{ Variable } & \multirow{2}{*}{\multicolumn{2}{|c|}{$\frac{\text { Precipitation }(y)}{\text { Soil water }(0-10 \mathrm{~cm})(x)}$}} & \multicolumn{4}{|c|}{ Soil water $(0-10 \mathrm{~cm})(y)$} \\
\hline & & & \multicolumn{2}{|c|}{$\begin{array}{l}\text { Soil water (below } 10 \mathrm{~cm} \text { ) } \\
(x)\end{array}$} & \multicolumn{2}{|c|}{$\begin{array}{l}\text { Soil water (below } \\
10 \mathrm{~cm})(x)\end{array}$} \\
\hline & $a \pm b x$ & $R^{2}$ & $a \pm b x$ & $R^{2}$ & $a \pm b x$ & $R^{2}$ \\
\hline $\mathrm{pH}$ (no unit) & $4.429+0.366 x$ & 0.30 & $5.655+0.125 x$ & 0.05 & $0.007+0.019 x$ & 0.001 \\
\hline Alkalinity $\left(\mathrm{mg} \mathrm{l}^{-1}\right)$ & $4.364+0.068 x$ & 0.01 & $6.583+0.106 x$ & 0.01 & $2.462+1.038 x$ & 0.45 \\
\hline Conductivity $\left(\mu \mathrm{S} \mathrm{cm}^{-1}\right)$ & $42.98+0.102$ & 0.02 & $47.51+0.095 x$ & 0.02 & $0.007-0.122 \mathrm{x}$ & 0.02 \\
\hline $\mathrm{Na}^{+}\left(\mathrm{mg} \mathrm{l}^{-1}\right)$ & $5.558-0.010 \mathrm{x}$ & 0.001 & $5.478-0.011 x$ & 0.001 & $2.913+0.446 x$ & 0.31 \\
\hline $\mathrm{K}^{+}\left(\mathrm{mg} \mathrm{l}^{-1}\right)$ & $0.053+0.001 x$ & 0.004 & $0.063+0.16 \mathrm{x}$ & 0.036 & $0.094+0.023 x$ & 0.001 \\
\hline $\mathrm{Mg}^{2+}\left(\mathrm{mg} \mathrm{l}^{-1}\right)$ & $0.939-0.058 x$ & 0.002 & $1.011-0.063$ & 0.003 & $0.456+0.556$ & 0.41 \\
\hline $\mathrm{Ca}^{2+}\left(\mathrm{mg} \mathrm{l}^{-1}\right)$ & $1.838+0.743 \mathrm{x}$ & 0.33 & $2.336+0.982 x$ & 0.03 & $2.307+0.179 x$ & 0.05 \\
\hline $\mathrm{NH}_{4}^{+}\left(\mathrm{mg} \mathrm{l}^{-1}\right)$ & $0.007+0.723 x$ & 0.32 & $0.009+0.44 \mathrm{x}$ & 0.32 & $0.010+0.44 \mathrm{x}$ & 0.32 \\
\hline $\mathrm{NO}_{3}^{-}\left(\mathrm{mg} \mathrm{l}^{-1}\right)$ & $0.097-0.001 x$ & 0.02 & $0.12-0.002 x$ & 0.018 & $0.070+0.483 x$ & 0.21 \\
\hline $\mathrm{Cl}^{-}\left(\mathrm{mg} \mathrm{l}^{-1}\right)$ & $8.698-0.026$ & 0.03 & $8.075+0.015 x$ & 0.02 & $15.6+0.756 x$ & 0.72 \\
\hline $\mathrm{PO}_{4}^{3-}\left(\mathrm{mg} \mathrm{l}^{-1}\right)$ & $0.005+0.008 x$ & 0.002 & $0.007-0.051 x$ & 0.009 & $0.007+0.019 x$ & 0.001 \\
\hline $\mathrm{SO}_{4}{ }^{2-}\left(\mathrm{mg} \mathrm{l}^{-1}\right)$ & $1.644-0.101 x$ & 0.004 & $1.852-0.147 \mathrm{x}$ & 0.006 & $1.614+0.121 x$ & 0.02 \\
\hline $\mathrm{Fe}\left(\mathrm{mg} \mathrm{l}^{-1}\right)$ & $0.004-0.073 x$ & 0.01 & $0.004+0.478 x$ & 0.18 & $0.007-0.122 \mathrm{x}$ & 0.02 \\
\hline $\mathrm{Al}^{3+}\left(\mathrm{mg} \mathrm{l}^{-1}\right)$ & $0.007-0.100 x$ & 0.05 & $0.007+0.261$ & 0.15 & $102.9+483.7 x$ & 0.01 \\
\hline
\end{tabular}

$R^{2}=$ Coefficient of determination are likely to be associated with noise and/or missing data. The red band, which indicates high disturbance in signals, appears to differ with either precipitation, soil water at $0-10 \mathrm{~cm}$ or soil water below $10 \mathrm{~cm}$, and with individual variable. Also, the pattern exhibited in the wavelet signal plots for $\mathrm{pH}$, conductivity and alkalinity that are composite variables in the study was more dispersed in the precipitation and at $0-10 \mathrm{~cm}$ than below it suggesting more impact of diffuse sources of contamination in the precipitation and topsoil $(0-10 \mathrm{~cm})$ than the soil below. In all, majority of 
(i) Precipitation

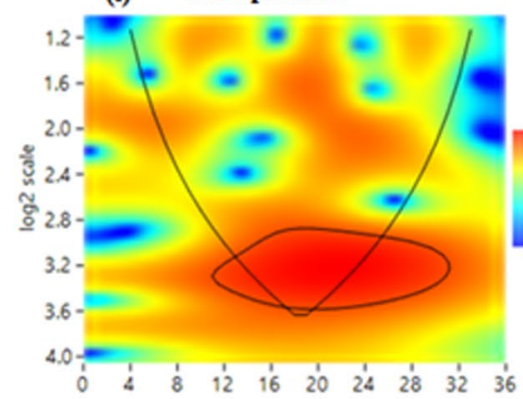

(i)

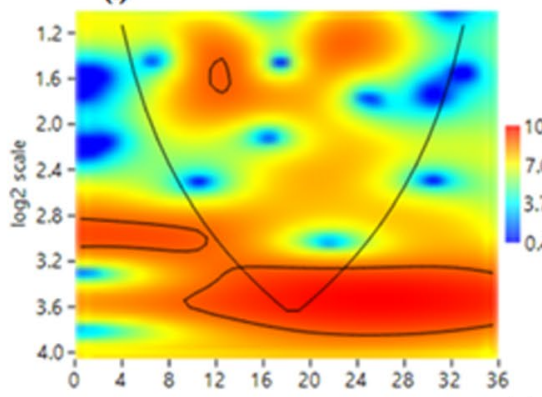

(i)

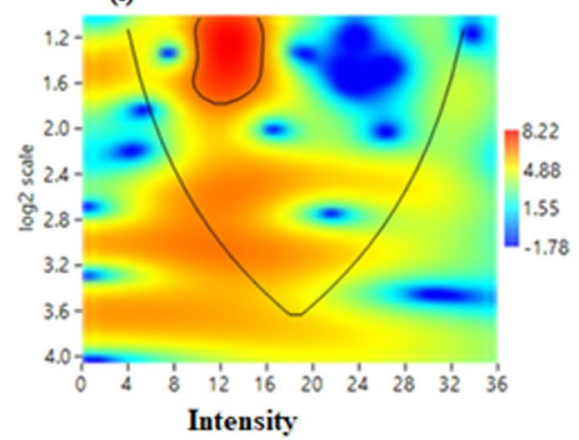

(a) $\mathrm{pH}$

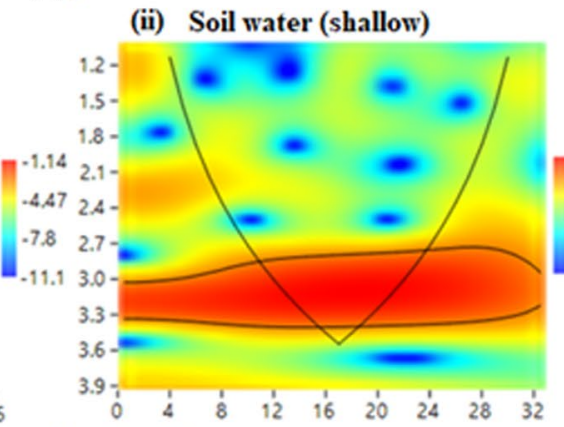

(b) Conductivity

(ii)

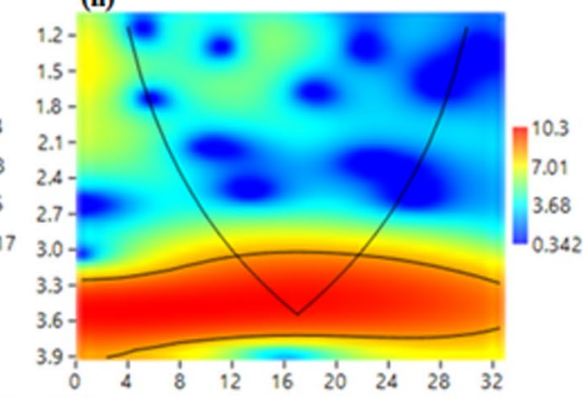

(ii)

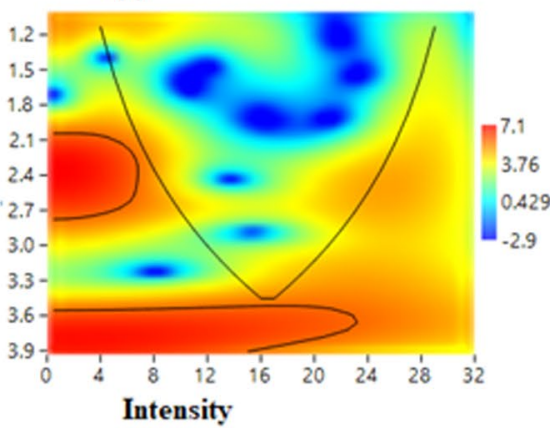

(iii) Soil water (deep)

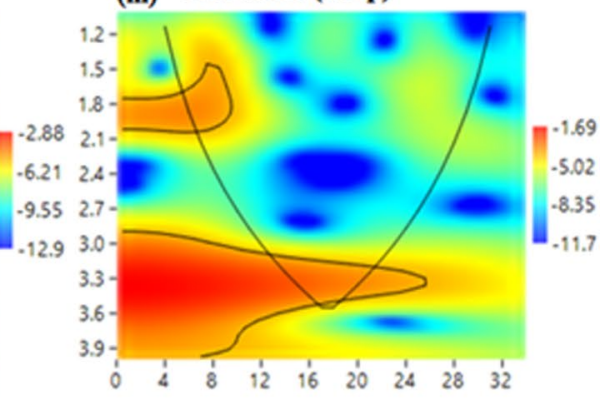

(iii)

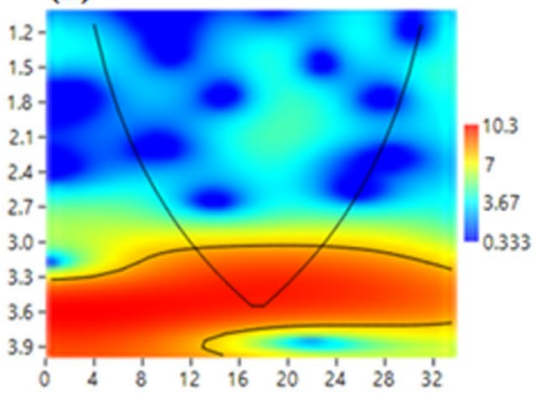

(iii)

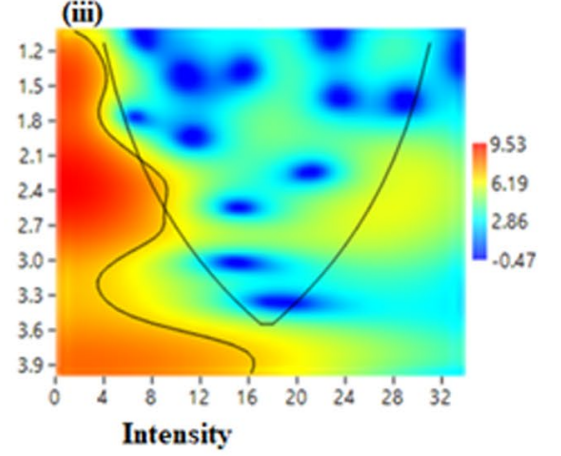

Fig. 5 Wavelet transform of selected physico-chemical variables in precipitation and soil water at the study area

the investigated variables exhibit signal responses that are relatively proximal between soil water at $0-10 \mathrm{~cm}$ and below $10 \mathrm{~cm}$ than between precipitation and either of the soil water type.

\section{Discussion}

The objectives of this study are to examine the temporal characteristics of precipitation and soil water chemistry and assess the relationship between the concentration of selected chemical variables in precipitation and soil water at both shallow $(0-10 \mathrm{~cm})$ and deep $(>10 \mathrm{~cm})$ in a typical agricultural settlement in the southwest England. The study area is characterized by Halstow soil series of Cambisol soil type that is known to support agricultural activities. The soil is characterized by $0.8-1.2 \mathrm{~g} \mathrm{~cm}^{-3}$, slightly mottled and stony clay loam or clay topsoil with low infiltration capacity (Boorman et al. 1995). Results of analysis showed that the precipitation in the area was fairly acidic and chemically dominated by $\mathrm{Cl}^{-}$and $\mathrm{Na}^{+}$as common anion and cation, respectively. The values of $\mathrm{pH}$ and the trend indicate that the study area precipitation in the study area cannot be described as acidic, and the region is not under a threat of significant acid rain. The relatively low acidity observed is normal and within the range that can be attributed to the removal of naturally occurring acids (that may have been introduced into the atmosphere by sea and non-sea salts sources) during any form wet deposition, including rainfall (Brown et al. 2000; Irwin et al. 2002). The specific effect of the different types of precipitation-snow, rainout, etc., on the level of acidity was not verified in this study, and further detail on the data will be required for this. Nonetheless, a comparison of the $\mathrm{pH}$ value with the observation of Porteous and Barratt 

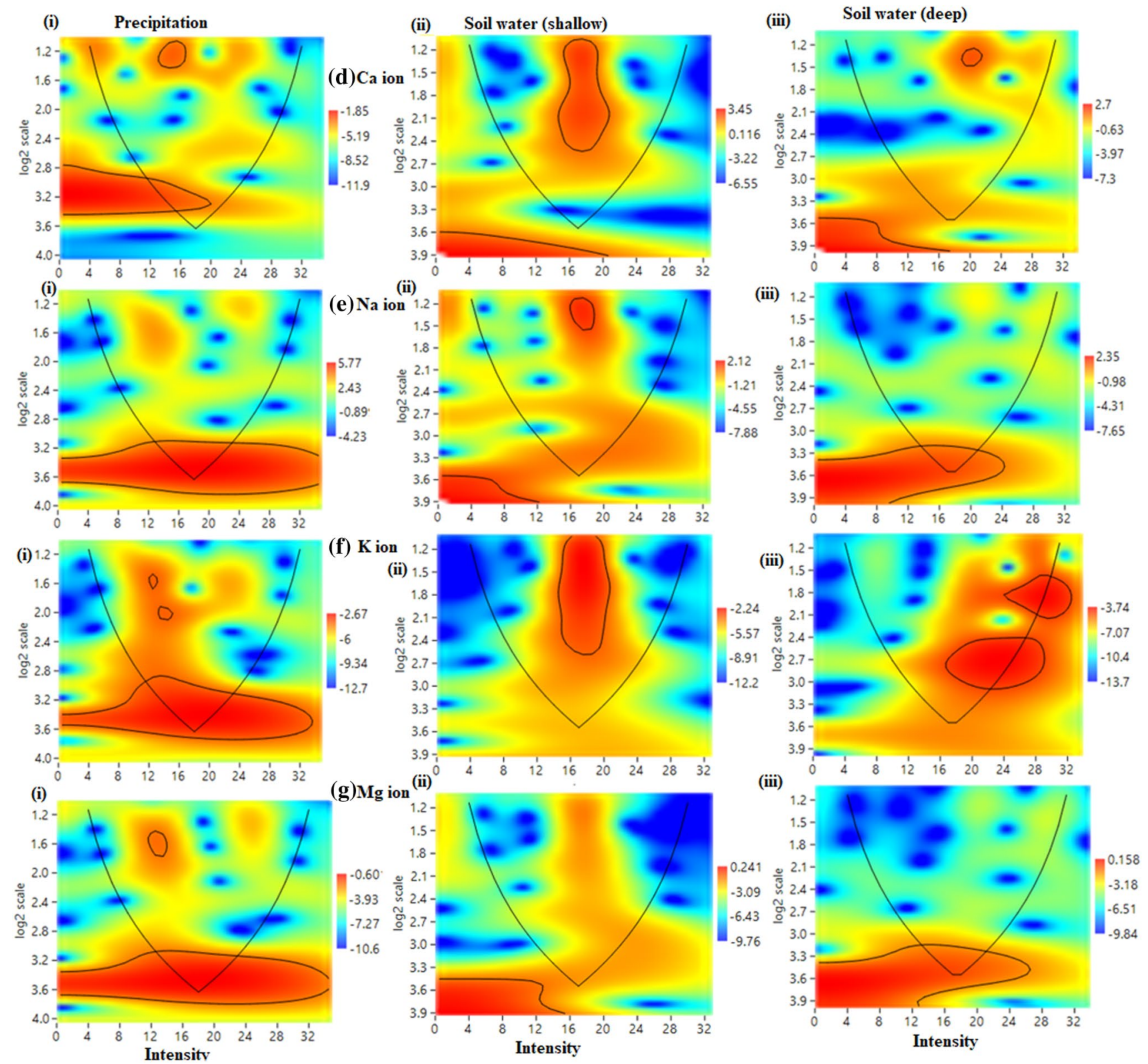

Fig. 5 (continued)

(1989) for the entire Devon area (median $\mathrm{pH}$ of about 5.6) in the southwest England indicates that the region is not under any serious threat of acid rainfall.

Comparison with the $\mathrm{pH}$ data from similarly rural parts of the UK, such as the Glendyle catchment, Aberdeen (with mean pH of 4.3; Reid et al. 1981), and three other sites in Aberdeenshire in 1986 (mean $\mathrm{pH}=4.8$; Porteous and Barratt 1989), suggests that the precipitation chemistry in this area of the southwest England is not a representative of the industrial region. Similar low level of acidic precipitation that was obtained in the study area was recorded at Puerto Morelos, Mexico and Gulf of Mexico in low industrialized region (Bravo et al. 2000). A comparison of the dominant ions $\left(\mathrm{Na}^{+}\right.$and $\mathrm{Cl}^{-}$) with some randomly (based on location such as centrality and proximity to ocean) selected ECN stations (Glensaugh; Aberdeenshire, Moor House-Upper Teesdale; Cumbria, Rothamsted; Hertfordshire; and Alice Holt, Hampshire) for the study period reflects the relative difference in the variations of the ions across the stationsalso indicating the relative temporal variability and concentration were higher at the study area than some other parts in the UK. Reid et al. (1981) associated temporal and relatively large variability to the combined effects of seasonal influence or climate, source enrichment and reactivity of the 
(i) Precipitation

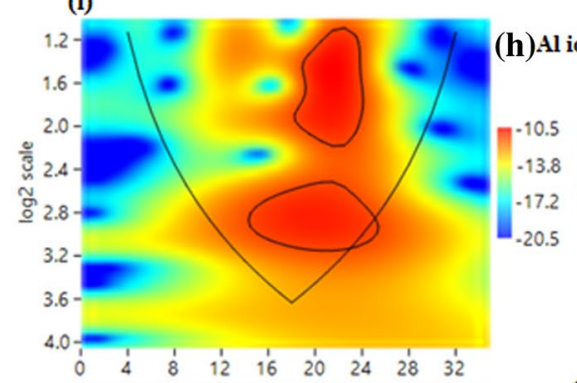

Soil water (shallow)

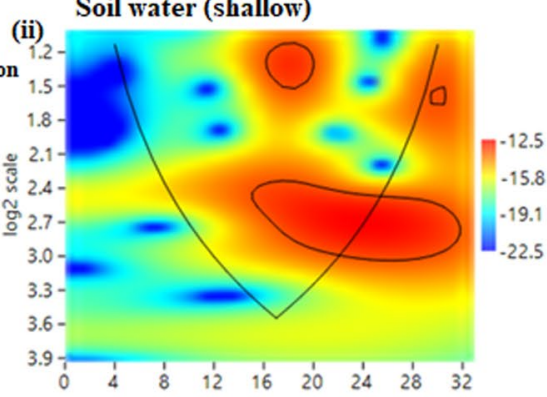

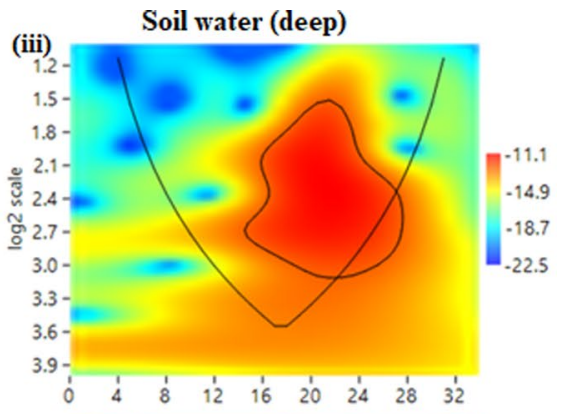
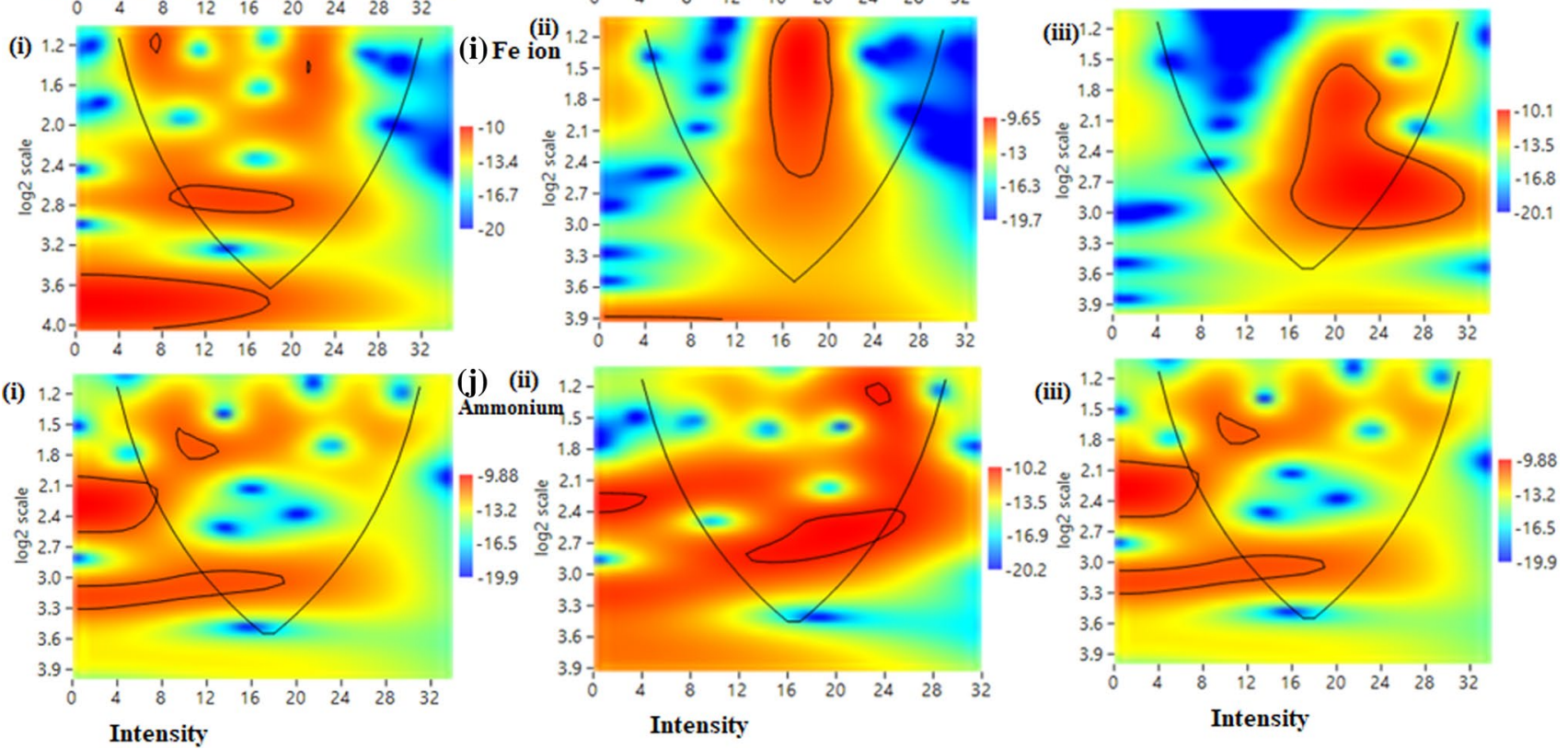

Fig. 5 (continued)

precipitation constituents. Subsequently, a source apportioning investigation of comparing the ion ratios with standard seawater (Reid et al. 1981; Thimonier et al. 2008; Chen et al. 2020) and anthropogenic references for industrial locations (Al-Khashman 2009) showed that variation in the precipitation chemistry in the study area could be attributed to sea sprays and terrestrial dusts (Table 4).

Soil water chemistry in the study area exhibited slightly lower acidity and lower concentrations of values of $\mathrm{PO}_{4}{ }^{3-}$, $\mathrm{Cl}^{-}, \mathrm{NO}_{3}{ }^{-}$and $\mathrm{K}^{+}$than were obtained in the precipitation. This is not surprising as the ions are more introduced to the environment through anthropogenic sources than natural sources, and might have been introduced as wet deposition through interaction with the atmosphere. On the other hand, variables $\left(\mathrm{Na}^{+}, \mathrm{Al}^{3+}, \mathrm{Mg}^{2+}, \mathrm{Ca}^{2+}\right.$, alkalinity and $\mathrm{SO}_{4}{ }^{2-}$ ) which occurred more in the soil than what was observed in the precipitation are generally related to the geological underlain of the area. Harrod and Hogan (1981) reported that the study area is underlain by Carboniferous Crackington Formation, and a part of 'Culm Measures' (sandstone and shale sequence of the extensive outcrop of
Carboniferous strata) in the Millstone Grit (Laming and Roche 2006). Many studies have linked geological materials in parts of the UK to groundwater sources (Heathcote and Lloyd 1984; Edmunds and Kinniburgh 1986; Ford and Tellam 1994; Czerewko et al. 2003), but the evidence of geological influence on soil water signals the importance of the influence of pre-event water.

Consequently, given the results of the wavelet analysis, PCA and ANOVA, a clear distinction apparently exists between the concentrations of certain chemical variables in the soil water and precipitation. The results provide support the hypothesis that saturation overland flow dominates the run-off mechanism in the study area (Eludoyin et al. 2017). Eludoyin et al. (2017) argued that inferences from the concentration-discharge characteristics from multiple events observed from the 15 farmlets of the Rothamsted Research's Farm Platform at North Wyke suggested that 'preferential passage of the installed French drains may only have enhanced the time taken by the run-off to reach the monitoring station, and not necessarily that the surface run-off in the heavy clay soil area in the region was caused

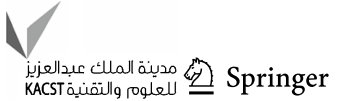


(i) Precipitation
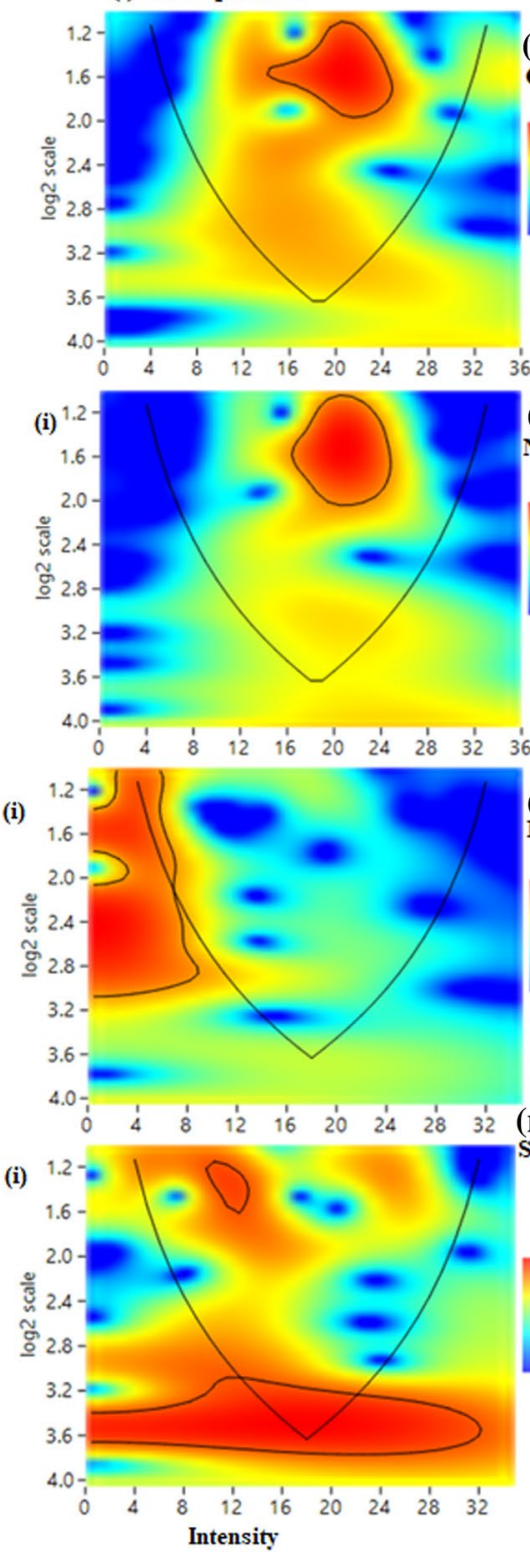

(ii) Soil water (shallow)
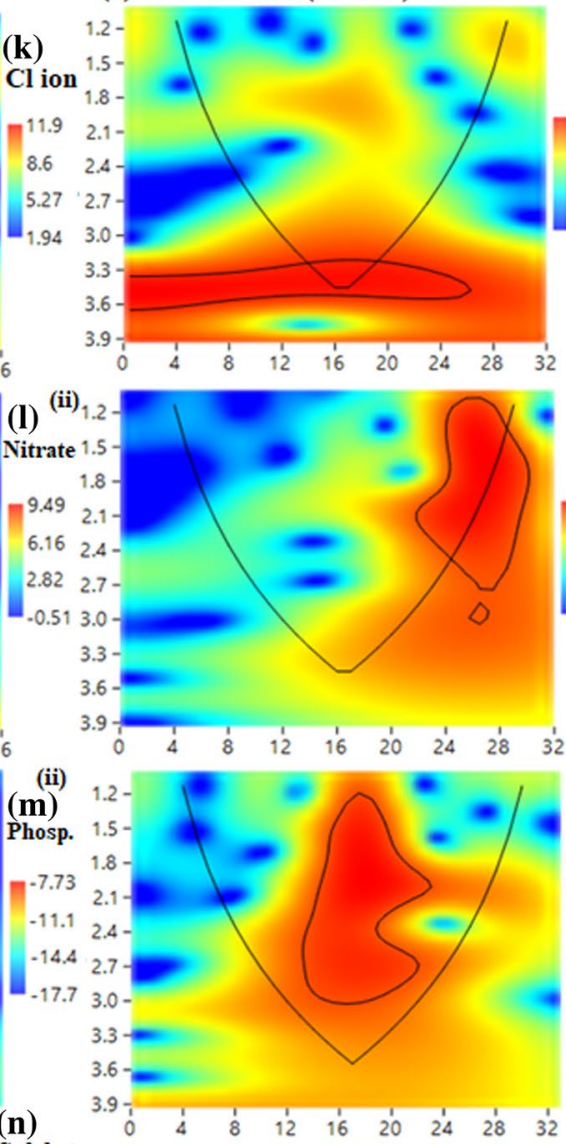

(n)

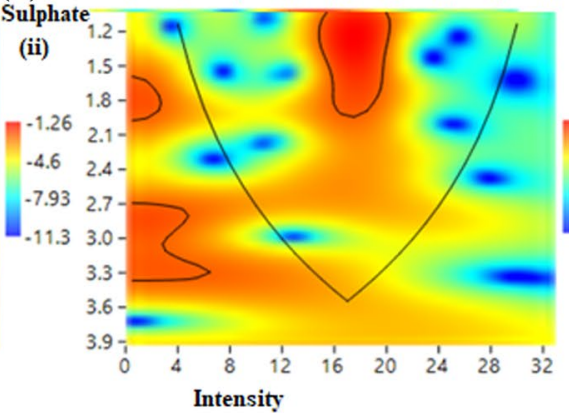

(iii). Soil water (deep)
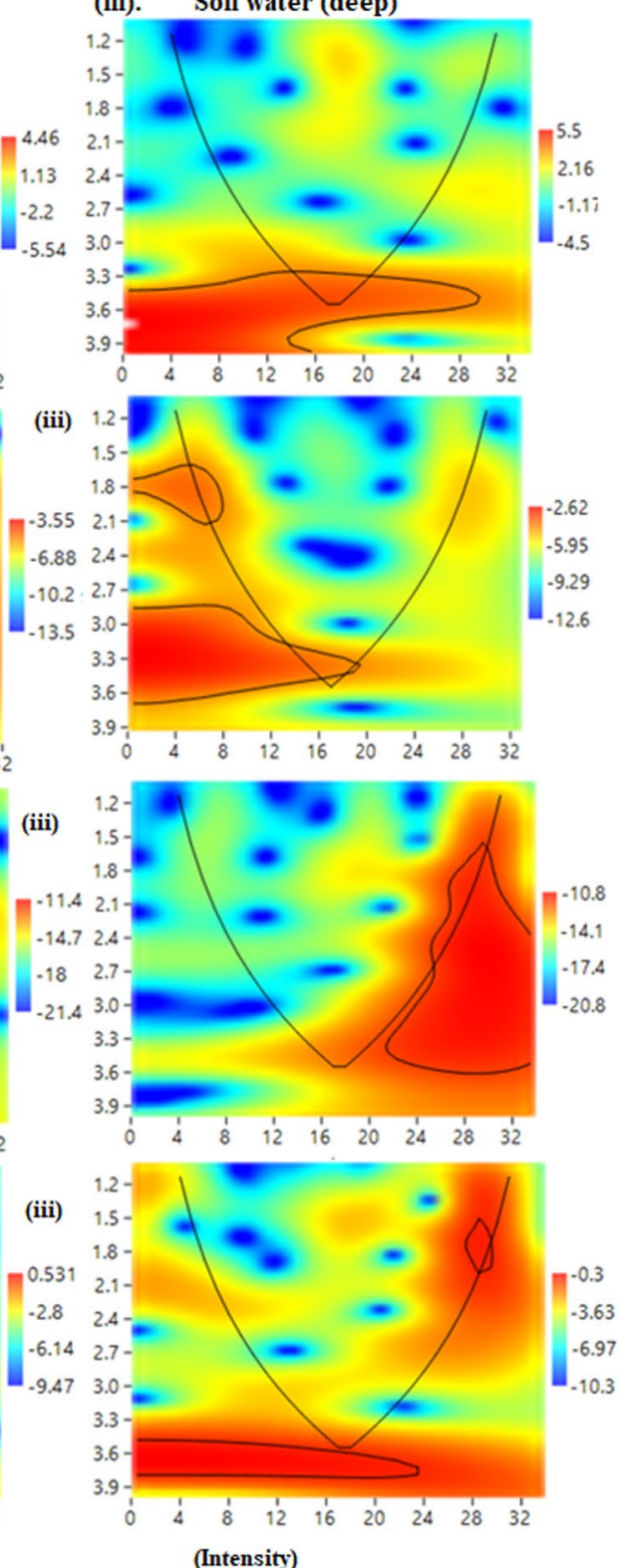

Fig. 5 (continued)

Table 4 Comparison of the ratio values of precipitation ions with the corresponding seawater ratio

\begin{tabular}{llcll}
\hline Ratio & Seawater ratio & This study & Comment on sources & Reference for seawater ratio \\
\hline $\mathrm{Na}^{+} / \mathrm{Cl}^{-}$ & 0.86 & 0.40 & Sea influence & Bravo et al. (2000), Thimonier et al. (2008) \\
$\mathrm{Mg}^{2+} / \mathrm{Na}^{+}$ & 0.23 & 0.23 & Sea influence & Berner and Berner (1987) \\
$\mathrm{Na}^{+} / \mathrm{K}^{+}$ & 27.63 & 27.00 & Sea influence & Reid et al. (1981) \\
$\mathrm{Na}^{+} / \mathrm{Ca}^{2+}$ & 26.25 & 2.60 & Terrestrial dusts & Krauskopf (1967), Reid et al. (1981) \\
$\mathrm{Cl}^{-} / \mathrm{SO}_{4}{ }^{2-}$ & 21.47 & 47.86 & Sea influence & \\
$\mathrm{SO}_{4}{ }^{2-} / \mathrm{NO}_{3}^{-}$ & - & 0.17 & Terrestrial dusts & Al-Khashman (2009) \\
$\mathrm{NO}_{3}{ }^{-} / \mathrm{Na}^{+}$ & 0.00002 & 0.30 & Terrestrial dusts & \\
$\mathrm{NH}_{4}^{+} / \mathrm{NO}_{3}^{-}$ & - & 0.02 & Terrestrial dusts & Lang and Elliott (1991) \\
\hline
\end{tabular}


Hortonian overland flow mechanism'. Saturation overland flow is explained by the variable source concept as run-off generated by the expansion of small, locally variable water table (known as 'contributing areas') during storm condition (Hewlett and Hibbert 1967; Dunne and Black 1970). In general, analysis of precipitation-soil water chemistry using the relatively long-term ECN data provides insights into hydrological behaviour in the area.

\section{Conclusion}

The study provided insights into hydrological flowpath at an intensively managed agricultural field from the relationship between precipitation and soil water chemistry using available ECN datasets. Identification of hydrological flowpath is one of the critical activity that targeted at providing basis for understanding diffuse pollution and contaminant transfer, among others, and thus requires fine data. The ECN datasets were therefore used complementarily with the Farm Platform records at North Wyke with the aim of improving the understanding of solute transfer in the area. The study showed temporal variability in precipitation and soil chemistry but did not show that either the soil or the precipitation was chemically impaired. Temporal variations in the precipitation chemistry were attributed to coastal influence and terrestrial dusts. Relationship between precipitation and soil water chemistry was weak, but mixing of the soil waters was indicated by the strong relationships of the chemistry at the two soil depth of water samples. Inference from the results suggests a possible significant role of pre-event water or geological influence on soil water chemistry. The study affirms the hypothesis that saturation overland flow dominates areas underlain by Halstow soil series in the area.

Acknowledgements The author acknowledges the kind support of the Environment Change Network, particularly Anita Shepherd, Deb. Beaumont and Lorna Sherrin at the Rothamsted-North Wyke Research Farm Platform for the kind release of data and authentication of data quality; the Obafemi Awolowo University/Education Trust Fund, Nigeria, for sponsorship of the author's doctoral degree at the University of Exeter, which made awareness of the existence of ECN datasets possible; my supervisors, Profs. Richard Brazier and Tim Quine for encouraging the use of ECN data; and the Farm Platform Group at North Wyke for support.

Open Access This article is licensed under a Creative Commons Attribution 4.0 International License, which permits use, sharing, adaptation, distribution and reproduction in any medium or format, as long as you give appropriate credit to the original author(s) and the source, provide a link to the Creative Commons licence, and indicate if changes were made. The images or other third party material in this article are included in the article's Creative Commons licence, unless indicated otherwise in a credit line to the material. If material is not included in the article's Creative Commons licence and your intended use is not permitted by statutory regulation or exceeds the permitted use, you will need to obtain permission directly from the copyright holder. To view a copy of this licence, visit http://creativecommons.org/licenses/by/4.0/.

\section{References}

Adamson JK (1996) Initial water handling. The United Kingdom environmental change network: protocols for standard measurements at terrestrial sites, The Stationery Office. http://www.ecn.ac.uk/ measurements/terrestrial/wh. Accessed 15 Oct 2010

Adamson JK, Sykes JM (1996) Precipitation chemistry: the United Kingdom environmental change network: protocols for standard measurements at terrestrial sites, The Stationery Office. http:// www.ecn.ac.uk/measurements/terrestrial/pc. Accessed 15 Oct 2010

Al-Khashman OA (2005) Study of chemical composition in wet atmospheric precipitation in Eshidiya area, Jordan. Atmos Environ 39(33):6175-6183

Al-Khashman OA (2009) Chemical characteristics of rainwater collected at a western site of Jordan. Atmos Res 91(1):53-61

Allen ST, Kirchner JW, Braun S, Siegwolf RT, Goldsmith GR (2019) Seasonal origins of soil water used by trees. Hydrol Earth Syst Sci 23(2):1199-1210

Avery BW (1980) Soil classification in England and Wales: higher categories. Soil Survey Technical Monograph No. 14. Harpenden, United Kingdom

Benettin P, Bailey SW, Rinaldo A, Likens GE, McGuire KJ, Botter G (2017) Young runoff fractions control streamwater age and solute concentration dynamics. Hydrol Process 31(16):2982-2986

Berner KB, Berner RA (1987) The global water cycle: geochemistry and environment. Prentice-Hall, New Jersey

Beven K, Germann P (1982) Macropores and water flow in soils. Water Resour Res 18(5):1311-1325

Beverland IJ, Crowther JM, Srinivas MSN, Heal MR (1998) The influence of meteorology and atmospheric transport patterns on the chemical composition of rainfall in south-east England. Atmos Environ 32(6): 1039-1048

Boorman DB, Hollis JM, Lilly A (1995) Hydrology of soil types: a hydrologically-based classification of the soils of United Kingdom. Institute of Hydrology, Wallingford

Bravo HA, Saavedra MIR, Sánchez PA, Torres RJ, Granada LMM (2000) Chemical composition of precipitation in a Mexican Maya region. Atmos Environ 34:1197-1204

Brown VA, McDonnell JJ, Burns DA, Kendall C (2000) The role of event water, a rapid shallow flow component, and catchment size in summer stormflow. J Hydrol 217:171-190

Cape N, Fowler D (1981) Changes in epicuticular wax of Pinus sylvestris exposed to polluted air. Silva Fennica 15:457-458

Cerny J, Billett MF, Cresser MS (1994) Element budgets. ScopeScientific Committee on Problems of the Environment International Council of Scientific Unions, vol 51, pp 189-189

Chen J, Qian H, Gao Y, Wang H, Zhang M (2020) Insights into hydrological and hydrochemical processes in response to water replenishment for lakes in arid regions. J Hydrol 581:124386

Cresser MS, Edwards A (1987) Acidification of freshwaters (No. 2). Cambridge University Press, Cambridge

Cresser MS, Harriman R, Pugh K (1987) Processes of acidification of soil and freshwaters. In: Proceedings the ICCET symposium on acid rain and Britain's natural ecosystems. Imperial College, London, ICCET, London

Czerewko MA, Cripps JC, Reid JM, Duffell CG (2003) Sulfur species in geological materials-sources and quantification. Cement Concr Compos 25(7):657-671 
Damgaard C, Strandberg M, Kristiansen SM, Nielsen KE, Bak JL (2014) Is Erica tetralix abundance on wet heathlands controlled by nitrogen deposition or soil acidification? Environ Pollut 184:1-8

Dunne T, Black RD (1970) An experimental investigation of runoff production in permeable soils. Water Resour Res 6(2):478-490

Edmunds WM, Kinniburgh DG (1986) The susceptibility of UK groundwaters to acidic deposition. J Geol Soc 143(4):707-720

Eludoyin AO (2013) Modelling the hysteretic patterns of solute concentration-discharge relationships and their significance for hydrological pathways at the farm scale. Doctoral Thesis, University of Exeter, United Kingdom. http://hdl.handle.net/10871/15374. Accessed 20 Aug 2014

Eludoyin AO, Griffith B, Orr RJ, Bol R, Quine TA, Brazier RE (2017) An evaluation of the hysteresis in chemical concentration-discharge $(\mathrm{C}-\mathrm{Q})$ relationships from drained, intensively managed grasslands in southwest England. Hydrol Sci J 62(8):1243-1254

Evans C, Davies TD (1998) Causes of concentration/discharge hysteresis and its potential as a tool for analysis of episode hydrochemistry. Water Resour Res 34(1):129-137

Evans CD, Chadwick T, Norris D, Rowe EC, Heaton TH, Brown P, Battarbee RW (2014) Persistent surface water acidification in an organic soil-dominated upland region subject to high atmospheric deposition: the North York Moors, UK. Ecol Ind 37:304-316

Farewell T (2008) National Soil Resources Institute, Soils Site Report, Cranfield University, United Kingdom, p 27

Ford M, Tellam JH (1994) Source, type and extent of inorganic contamination within the Birmingham urban aquifer system, UK. J Hydrol 156(1-4):101-135

Giusti L, Neal C (1993) Hydrological pathways and solute chemistry of storm runoff at Dargall Lane, southwest Scotland. J Hydrol 142:1-27

Hall DJ (1986) The precipitation collector for use in the Secondary National Acid Deposition Network. Warren Spring Laboratory, Stevenage, LR 56I (AP)

Hammer Ø (2016) PAST. PAlentological statistics. Reference Manual, p 252

Harrod T, Hogan D (1981) The soils of North Wyke and Rowden. Unpublished report to North Wyke Research, revised edition of original report by TR Harrod, Soil Survey of England and Wales. http://www.rothamsted.ac.uk/sites/default/files/SoilsNWRowden. pdf. Accessed 15 Oct 2010

Heathcote JA, Lloyd JW (1984) Groundwater chemistry in southeast Suffolk (UK) and its relation to Quaternary geology. J Hydrol 75(1-4):143-165

Hewlett J, Hibbert A (1967) Factors affecting the response of small watersheds to precipitation in humid areas. For Hydrol 1:275-290 (Reprint from International Symposium of Forest Hydrology. Proceeding of National Science Found Advanced Science Seminar at Penn. State Univ. 1965, Pergamon Press-Oxford \& New York, 1966)

Heyes CJ, Irwin JG, Barrett CF (1985) Acid deposition monitoring networks in the United Kingdom. In: Advancements in air pollution monitoring equipment and procedures, pp 155-168

HMSO (1978) The measurement of electrical conductivity and the laboratory determination of the $\mathrm{pH}$ value of natural, treated and waste waters. HMSO, London

HMSO (1988) The determination of $\mathrm{pH}$ in low ionic strength waters. HMSO, London

Hsu CS, Suen NT, Hsu YY, Lin HY, Tung CW, Liao YF, Chan T-S, Sheu H-S, Chen S-Y, Chen HM (2017) Valence-and elementdependent water oxidation behaviors: in situ X-ray diffraction, absorption and electrochemical impedance spectroscopies. Phys Chem Chem Phys 19(13):8681-8693
Irwin JG, Campbell G, Vincent K (2002) Trends in sulphate and nitrate wet deposition over the United Kingdom, 1986-1999. Atmos Environ 36:2867-2879

Jenkins A, Ferrier RC, Harriman R, Ogunkoya YO (1994) A case study in catchment hydrochemistry: conflicting interpretations from hydrological and chemical observations. Hydrol Process 8(4):335-349

Jia X, Tang J, Zhang Y (2019) The precipitation chemistry and acidity over China during 2018. In: E3S web of conferences, vol 136. EDP Sciences, $\mathrm{p} 06020$

Krauskopf KB (1967) Introduction to geochemistry. McGraw-Hill, New York

Kvaalen H, Solberg S, Clarke N, Torp T, Aamlid D (2002) Time series study of concentrations of $\mathrm{SO}_{2}^{-}$and $\mathrm{H}^{+}$in precipitation and soil waters in Norway. Environ Pollut 117(2):215-224

Laming D, Roche D (2006) Devon geology guide-carboniferous sandstones and shales. http://www.devon.gov.uk/geo-carboniferoussa ndstonesandshales.pdf. Accessed 15 Oct 2010

Lane AMJ (1997) The UK environmental change network database. An integrated information resource for long-term monitoring and research. J Environ Manag 51(1):87-105

Lang HJ, Elliott GC (1991) Influence of ammonium: nitrate ratio and nitrogen concentration on nitrification activity in soilless potting media. J Am Soc Hort Sci 116:642-645

Lark RM, Webster R (2001) Changes in variance and correlation of soil properties with scale and location: analysis using an adapted maximal overlap discrete wavelet transform. Eur J Soil Sci 52(4):547-562

Leslie AB, Burt C, Chacksfield B, Waters C (2008) Structure of the Culm Basin: rapid mapping of the Tiverton Sheet and the latest Variscan inversion in Devon. Geosci South-West Engl Proc Ussher Soc 11(4):298-304

McDowell WH, Brereton RL, Scatena FN, Shanley JB, Brokaw NV, Lugo AE (2013) Interactions between lithology and biology drive the long-term response of stream chemistry to major hurricanes in a tropical landscape. Biogeochemistry 116(1-3):175-186

McGivney E, Gustafsson JP, Belyazid S, Zetterberg T, Löfgren S (2019) Assessing the impact of acid rain and forest harvest intensity with the HD-MINTEQ model-soil chemistry of three Swedish conifer sites from 1880 to 2080. Soil 5(1):63-77

McHale MR, Burns DA, Siemion J, Antidormi MR (2017) The response of soil and stream chemistry to decreases in acid deposition in the Catskill Mountains, New York, USA. Environ Pollut 229:607-620

Miller AJ, Zégre NP (2014) Mountaintop removal mining and catchment hydrology. Water 6(3):472-499

Milne AE, Macleod CJA, Haygarth PM, Hawkins JMB, Lark RM (2009) The wavelet packet transform: a technique for investigating temporal variation of river water solutes. J Hydrol 379(1-2):1-19

Morecroft MD, Bealey CE, Beaumont DA, Benham S, Brooks DR, Burt TP, Critchley CNR, Dick J, Littlewood NA, Monteith DT, Scott WA (2009) The UK Environmental Change Network: emerging trends in the composition of plant and animal communities and the physical environment. Biol Cons 142(12):2814-2832

Neal C, Wilkinson J, Neal M, Harrow M, Wickham H, Hill L, Morfitt C (1997) The hydrochemistry of the headwaters of the River Severn, Plynlimon. Hydrol Earth Syst Sci 1:583-617

Porteous A, Barratt RS (1989) A short term survey of daily rainfall acidity in the UK. Atmos Environ (1967) 23(2):509-512

Reid JM, MacLeod DA, Cresser MS (1981) Factors affecting the chemistry of precipitation and river water in an upland catchment. $\mathrm{J}$ Hydrol 50:129-145

Rodwell JS (1992) Grassland and Montane communities. British Plant Communities, vol 3. Cambridge University Press, Cambridge

Sigler WA, Ewing SA, Jones CA, Payn RA, Brookshire EJ, Klassen JK, Jackson-Smith D, Weissmann GS (2018) Connections among 
soil, ground, and surface water chemistries characterize nitrogen loss from an agricultural landscape in the upper Missouri River basin. J Hydrol 556:247-261

Song X, Wang P, Yu J, Liu X, Liu J, Yuan R (2011) Relationships between precipitation, soil water and groundwater at Chongling catchment with the typical vegetation cover in the Taihang mountainous region, China. Environ Earth Sci 62(4):787-796

Soulsby C, Petry J, Brewer MJ, Dunn SM, Ott B, Malcolm IA (2003) Identifying and assessing uncertainty in hydrological pathways: a novel approach to end member mixing in a Scottish agricultural catchment. J Hydrol 274(1-4):109-128

Sykes JM, Lane AMJ (1996) The UK Environmental Change Network: protocols for standard measurements at terrestrial sites. The Stationery Office, London

Thimonier A, Schmitt M, Waldner P, Schleppi P (2008) Seasonality of the $\mathrm{Na} / \mathrm{Cl}$ ratio in precipitation and implications of canopy leaching in validating chemical analyses of throughfall samples. Atmos Environ 42(40):9106-9117

Torrence C, Compo GP (1998) A practical guide to wavelet analysis. Bull Am Meteor Soc 79(1):61-78

Warrington G, Barclay WJ, Leveridge BE, Waters CN (2012) The global Devonian, Carboniferous and Permian Correlation Project: a review of the contribution from Great Britain. Geosci SouthWest Engl 13:47-51

Wymore AS, Leon MC, Shanley JB, McDowell WH (2019) Hysteretic response of solutes and turbidity at the event scale across forested tropical montane watersheds. Front Earth Sci Biogeosci 7:126. https://doi.org/10.3389/feart.2019.00126

Xie H, Dong J, Shen Z, Chen L, Lai X, Qiu J, Wei G, Peng Y, Chen X (2019) Intra-and inter-event characteristics and controlling factors of agricultural nonpoint source pollution under different types of rainfall-runoff events. Catena 182:104105

Zhi W, Li L, Dong W, Brown W, Kaye J, Steefel C, Williams KH (2019) Distinct source water chemistry shapes contrasting concentration-discharge patterns. Water Resour Res 55(5):4233-4251

Publisher's Note Springer Nature remains neutral with regard to jurisdictional claims in published maps and institutional affiliations. 